\title{
Study on the Mental Health of Impoverished College Students Education
}

\author{
Yucheng Fan \\ College Students' Psychological Development and Education Center, Southwest Petroleum University, Chengdu, China \\ Email: fanyucheng2018@163.com
}

How to cite this paper: Fan, Y. C. (2018) Study on the Mental Health of Impoverished College Students Education. Creative Education, 9, 870-878.

https://doi.org/10.4236/ce.2018.96064

Received: March 5, 2018

Accepted: May 11, 2018

Published: May 14, 2018

Copyright $\odot 2018$ by author and Scientific Research Publishing Inc. This work is licensed under the Creative Commons Attribution International License (CC BY 4.0).

http://creativecommons.org/licenses/by/4.0/

\section{cc) (i) Open Access}

\begin{abstract}
With economic and social development, the psychological health problems of poor college students present new characteristics and new situation. Psychological causes become more complex and malignant events happen frequently. To solve the adverse psychological conditions is urgently needed in the college students' education work. Poor college students work, is to be about colleges and universities in the new period of cultivating qualified builders and reliable successors for the socialist basic task, according to a new problem, to explore the root causes, to find the effective method to solve the problem of poor college students' mental health, and improve the pertinence and effectiveness of poor college students' mental health work, to do a good job in people's satisfactory education, train and bring up all-round development of socialist builders and successors.
\end{abstract}

\section{Keywords}

Mental Health, College Students, Psychological Health Problems

\section{Introduction}

With the reform of China's economic system and the reform of education system, it is an important issue that the current educational circles and the whole society are concerned about. Since the enrollment expansion of colleges and universities in 1999, China's higher education has gone from elitist to popularization, and more and more young students have been given the opportunity to enter the university to accept education. However, the problem of poor college students gradually expanded, and showed a trend of rising year by year, and the poor students in colleges and universities in recent years happened extreme events, letting originally the problems of poor students in colleges and universities gradually become the focus of the development of higher education and the 
attention of the society. Solving the problem of poor college students' mental health has also become the urgent need of humanistic care and influenced the stability of the campus (Kremer \& Hofman, 1985).

Because of China's regional economic differences and the gap between rich and poor, grand development in higher education and universities charge policy, the relatively high tuition and the cost of living become a heavy burden of family for those economic difficulties students. Thus a large number of poor college students groups appeared. According to statistics, the proportion of poverty-stricken students in China's colleges and universities is about 20 percent, and the proportion of poverty-stricken students is 8 percent, and the number of poverty-stricken college students has exceeded 4 million. According to one statistic, the necessary expenditure of Chinese college students accounts for $67 \%$ of their total household expenditure and even $87 \%$ of rural households. Poor college student is a special and disadvantaged group of college students. They are facing economic pressure and difficulties in study and life. These negative factors for their education, interpersonal relationship, emotional aspects bring such as anxiety, pessimism, anger, depression, self closed, abandon, cynical, bad mood and mental health problems such as risk factors for the campus and society under the ground. The Ma Jiajue Event has given an alarm for the mental health education on undergraduates, and the ideological and political work in colleges is also facing the great challenge. To explore the poor college students' mental health status and find the right ways of psychological health education work are the current work problems to be resolved in the poor college students' mental health education in colleges and universities.

Telling from the practice, the significance of the research is to help poor college students set up healthy mentality, guide them to a positive attitude to face learning and life, grow up to be a qualified citizen of physical and mental health. At the same time, this article analyzed the psychological health problems of poor college students and developed feasible countermeasures. It makes education workers in colleges and universities comprehensively understand the present poor college students' psychological health and find the practical and feasible countermeasures in psychological education work, which in turn further provide powerful basis for student work. In theory, the study of this article is advantageous to enrich the study of psychological health problems of poor college students and expand college students' ideological education work research. And it has positive significance on the improvement of the poor college students.

\section{Mental Health Status and Major Psychological Problems of Poor College Students}

Most poor college students have a negative outlook on health. They are not confident in their future predictions and assessments, but there are also some poor students with good attitudes. The main performances are:

1) the complex psychological state is displayed in special cases. 
Most poor college students have complicated and difficult living conditions. According to statistics (Gilbody, 2018), 73\% of the poor students from the countryside or town, their home are often in remote areas, farmer income is low, can't go out to work for various reasons, the family no sustained economic sources and protection; six percent of poor students are orphans or single parent families, while one or both of the parents died of illness, and the family economic poverty is accompanied by a heavy psychological trauma (Wei, 2008). 50\% of poor students, their parents or grandparents and other family members, lose labor ability, the status of the perennial is ill in bed, this not only spent a lot of money, but also the consumption of health workers to take care of the family economy; About $26 \%$ of the poor students belong to more than two families, which is mainly rural, with large family expenses and unable to support many children. These unfavorable factors bring the spirit of the poor college students and living pressures and worries, let them early to bear the burden of life, also give their character, personality and social cognitive complex effects. On the one hand, they are self-reliant, strong-willed, positive and able to face difficulties and challenges head-on. On the other hand, the special growth background and life experience can make them pessimistic, negative, cowardly, rebellious, aggressive and so on.

2) excessive self-abasement and extreme self-respect under the conditions of economic weakness.

Self-abasement is a psychological characteristic of the poor college students. The difficulty of family economy leads to the necessity of frugality in the daily life of impoverished students, which makes them have a great contrast with the living conditions of the students around them, which makes them feel inferiority to some extent (Yu \& Liu, 2006). With the economic and social development, daily necessities of college students are increasingly high, computer, ipod, smart phones and other electronic equipment in college students groups gradually popularization, for the struggle financially poor students, has a computer economic spending will exacerbate poverty of life, cause more psychological gap, and follow in the inferiority of the lack of a computer (Gao, Qiao, \& Song, 2011).

Due to the low self-esteem of the poor students, they are more sensitive than other students, have a stronger sense of self-protection, and have higher self-esteem than their peers. According to the survey, many students would rather "secretly" outside school work-study job, in order to change their economic status, are reluctant to accept the funding of the school, the students help or social sponsorship. Although their economy is extremely bad, but subconsciously refused to others to understand and get into their lives, refused to others' material support, the status quo are its strong self-esteem (Gaziel, 1995).

3) self-cognition is asymmetrical and interpersonal pressure is great.

The self-evaluation of poor college students is significantly different from that of others. They are more negative about their own cognition, more concerned about their own shortcomings, self-evaluation is far less than the actual situa- 
tion, and ignore or despise their positive image and advantages. The cognition of non-poor college students to poor college students is more positive. Due to the lack of confidence and poor self-evaluation, poor college students are not sociable, silent and self-defensive in interpersonal communication. Because of a variety of reasons, in dealing with the problem, most poor students cannot be in a positive state of mind, cannot objectively and rationally recognize and evaluate the people and things around them (Kremer-Hayon, Faraj, \& Wubbels, 2002).

4) experienced in stress, depression and recurrent anxiety.

Faced with the same situation, the impoverished college students' experience of pressure and frustration is obviously deeper than that of the non-poor college students. After entering university, the native of poor college students to bring home for identity, their outlook on life, world outlook, values, and language habits, behavior, style and other aspects of the sign of tangible or intangible, and the poor college students have bigger difference, this situation is easy to bring poor college students inner psychological conflict, characterized by low self-esteem, depression, conflict, anxiety, etc., leading to psychological self sealing and interpersonal difficulties. Under the effect of various factors, the poor college students psychological trouble, often do not choose consulting psychological doctor, if can't get the right solution, will further intensify their psychological problems (Hall \& Moss, 1998).

5) there is an identity difference between poor college students and non-poor students.

Due to the current Chinese society are larger gap between the rich and the poor, the poor students and the poor living environment is different, different life experiences, cause they are in the way of life, behavior standards, there are significant differences on value concept psychological pattern. On the one hand, the poor college students experienced hardship, prematurely tasting the life difficult, their cognitive maturity of society to the poor students, they more emphasis on the arduous struggle in life, study hard, work and rest regularly, learning in a planned way. On the other hand, non-poor students are relatively "childish", have fun, have a comfortable life, and pursue entertainment and relaxation. From two different environmental groups larger cognitive differences, in mutual recognition between them are insurmountable gap, if communication, in the long term, contradictions and frictions, in their life easily happened in a special incentive, under the catalysis of a possible opposite, fighting violence or criminal cases, etc. (Hall \& Chandler, 2005).

\section{Factors Affecting the Mental Health of Poor College Students}

Complex and varied factors, which affect the poor college students mental health, sums up the main entrance before and after the differences in living environment, such as "money worship" bad style of erosion, family, environmental impact, environmental impact and the problems of poor college students themselves.

1) differences in living environment before and after admission. 
The environment of poor college students before and after entering the university is very different. According to the survey by our university in 2016, from China's current level of consumption, in general undergraduate students, for example, one undergraduate spends at least 1600 \$ (including tuition, books, food, etc.), need at least $7000 \$$, 4 years this number for low-income urban families and rural families, amount to a astronomical figures. First of all, the living environment has changed a lot. Secondly, college students' consumption concept is very different. Finally, differences in lifestyle. The life of impoverished college students is relatively monotonous, usually the dormitory, the classroom, the dining hall at the first line, the spare time is usually the library books, part-time jobs or work-study. In addition to their study, non-poor college students have a variety of extracurricular activities, usually taking part in activities such as parties, Tours and football matches. The poor college students' life is influenced by the life of the non-poor college students. It is very easy to be psychologically unbalanced, and it can also produce the complex emotions such as "envy and jealousy".

2) the erosion of unhealthy practices such as "money worship".

Under the market economy tide impact, hidden a money worship of money society undercurrent, this to how much money as a standard to measure success or not of hidden rules, make poor students easy to form the idea of money is everything, their cash-strapped, status did not have money, being looked down upon, psychological unbalance, disappointment and embarrassment.

3) severe employment pressure.

Currently, the employment mode of college students is independent choice and two-way choice. In the environment of market economy, some unfair factors are avoided in the employment process of college students. But in excellent enterprises staff recruitment, because of poor college students family living environment and the poor college students have bigger difference, and is not an advantage in terms of temperament, speech, image, bring their employment more severe pressure, causing anxiety, panic, depression, anger and other adverse psychological problems.

4) influence of family environment.

The direct cause of the phenomenon of impoverished college students is family economic difficulties. Before entering the university, the life and learning environment of the impoverished students was relatively simple, especially in the hometown. The family environment of the students was similar, and the poverty problem was not obvious. But after the poor students entered the university, they immediately formed a sharp contrast with the economic situation of their classmates (Zhang, 2011).

\section{To Solve the Mental Health Problems of Poor College Students}

Colleges and universities must from set out actually, face of poor college students' mental problems, adopt corresponding work measures to help them to 
solve the economic difficulties, at the same time, more guidance to help them to shape healthy personality, establishing guarantee system, from the system and the system guarantee for the healthy development of their body and mind, grow up (Sun, Yu, \& Tian, 2005).

1) strengthen the psychological health of impoverished college students education.

Education workers in colleges and universities should aim to help poor college students form a healthy mental state and strengthen the psychological health of impoverished college students' education, which is of great practical significance. With the development of society, the state has increased the investment of education in higher education year by year, and the change of concept and the increase of funds have laid the foundation for the psychological health of the poor college students. In recent years, has become more and more attention to poor college students in colleges and universities to strengthen psychological health education, most colleges and universities set up psychological consulting room, provided by professional teachers for students psychological counseling, mental health counseling. This way to the school early understanding of poor college students' psychological problems, solving to suit the remedy to the case, early treatment for their psychological counseling, and ensure the healthy growth of poor students, maintain campus stability is of great significance.

Many colleges and universities have carried out psychological tests of poor college students at the beginning of their freshman enrollment, and the scientific classification has established the psychological archives of poor college students. This is a great breakthrough and innovation of education. But most psychological archives work in colleges and universities stop there, not on a regular basis or in a major event occurs following poor college students psychological testing and counseling, psychological archives lack of follow-up, when the poor college students mental health problem, cause the lack of "case", continuous tracing investigation material shortage, for poor college students' psychological problems research difficult.

College psychological education workers should through the poor college students mental care and encouragement, make them get rid of economic poverty brings psychological problems, help to set up the consciousness of independence, raise psychology to bear ability, make them right in the face of adversity, not flinch from difficulties, face actively, courage. In the end, it is necessary to strengthen the campus culture construction, to influence people and mold people in a good and harmonious campus environment, and to create favorable external conditions for the growth of poor college students.

2) strengthen the ideological and political education and set up the correct concept.

The psychological problems of poor college students are directly attributable to the family economic difficulties, and the root cause is the deviation of their 
world outlook, outlook on life and values. To strengthen the ideological and political education of poor college students, help them set up the correct world outlook, the outlook on life and values, to effectively solve the psychological health problems of poor college students, has a practical significance. The psychological problems of poor college students are closely related to the lack of lofty ideals and the lack of strong belief in overcoming difficulties. Give them positive and optimistic in the face of life and learning, and really solve the problem of poor college students' mental health, smooth finish school, we must strengthen the ideological and political education of them, help them set up correct world view, sets up the broad ideal and firm belief in life.

To fundamentally solve the problem of poor college students difficult economic and psychological, it is not enough to rely on outside help, teach them to fish than teach them to fish, only the poor college students set up the correct outlook on life, has the quality of free-standing self-improvement, bears hardships and stands hard work, can have the ability to shake off poverty.

3) strengthen psychological counseling for poor college students.

In view of the psychological problems of impoverished college students, colleges and universities should take effective measures to organize psychological experts to carry out the guidance of study, life and psychological development. For example, by a psychology class meeting, organize activities of psychological development, hold special lectures on the education for psychological knowledge, education for typical cases, etc., guide the poor college students to learn psychological adjustment, help them build up confidence and improve themselves, character. In this way, it can help the poor students to face the reality, adapt to the living environment, and improve their ability of mental health care and treatment. University psychology education workers want them to realize that poverty is a temporary reality, not a defect. Hard work and hard work can change the face of poverty. Lecture, also can through questionnaires, collective, individual interviews, and other forms of psychological counseling, to found a psychological crisis and psychological barriers of students and guidance in time treatment, should cooperate with family when necessary, to ease the pressure on students, the students well through common effort. Can also organize activities such as poor college students helping each other and pass love, let them experience was needed their luminous fever, pride, and understand that there are more and more people have family economic difficulties, there are also more difficult than itself, gradually get rid of the psychological shadow because of the poor.

4) material assistance is necessary.

Poverty is the root cause of poor college students have psychological problems, so to solve their psychological problems, let them grow talents for the society, must first to help them out of the extreme difficulty, remove their worries.

5) employment assistance helps alleviate the worries of poor students.

The economic plight of impoverished college students is the current situation 
which is difficult to change in the short term, and the basic way to solve this problem is to obtain employment smoothly. In the current severe employment situation, the employment of poor college students is more abrupt. The employment of poor college students is closely related to their own development, which is related to the welfare of their native families, which is more related to the reputation, benign development and social stability of the university. Poor college students is the vulnerable groups in the workforce, lack of social resources, family economic difficulties, their comprehensive quality and ability, various kinds of factors are affecting, employment difficulties make poor students groups. As colleges and universities, in addition to create a good learning and living environment for poor students, providing them with the necessary psychological counseling, more should put more energy in the ideological and political education work, strengthen the employment support, mutual cooperation, coordination, promote the poor college students full employment.

\section{Conclusion}

As the disadvantaged group of college students, poor college students have aroused wide concern in school and society. Psychological health problem of poor college students is the important topic of higher education that cannot be ignored, and education workers find the feasible countermeasure, through the efforts to make them happy and growing up healthily, to think and solve problems. Poor college students mental health status, from microscopic view, is related to my life, study, employment, and from macroscopic view, relationship to the family's rise and fall and the stability of colleges and universities, the country's rise and fall will be long-term and profound influence. Under the new situation, in the face of all kinds of social contradictions that emerge endlessly, we must continue to study poor college students' psychological problems, new contradictions derived from analysis of social events that influence on college students, analyze the new psychological problems, suit the remedy to the case, and solve the mental health problems of poor college students. As they grow up and do the help and protection, leading them to walk road life is the most beautiful period of a few steps.

\section{References}

Gao, Y., Qiao, Z. H., \& Song, H. T. (2011). Present Situation and Future of Professional Identity Study. Journal of Beijing Normal University (Social Sciences), 4, 47-53.

Gaziel, H. H. (1995). Sabbatical Leave, Job Burnout and Turnover Intentions among Teachers. International Journal of Lifelong Education, 14, 331-338. https://doi.org/10.1080/0260137950140406

Hall, D. T., \& Chandler, D. E. (2005). Psychological Success: When the Career Is a Calling. Journal of Organizational Behavior, 26, 155-176. https://doi.org/10.1002/job.301

Hall, D. T., \& Moss, J. E. (1998). The New Protean Career Contract: Helping Organizations and Employees Adapt. Organizational Dynamics, 26, 22-37.

https://doi.org/10.1016/S0090-2616(98)90012-2 
Kremer, L., \& Hofman, J. E. (1985). Teachers' Professional Identity and Burn-Out. Research in Education, 34, 89-95. https://doi.org/10.1177/003452378503400106

Kremer-Hayon, L., Faraj, H., \& Wubbels, T. (2002). Burn-Out among Israeli Arab School Principals as a Function of Professional Identity and Interpersonal Relationships with Teachers. International Journal of Leadership in Education, 5, 149-162. https://doi.org/10.1080/13603120110057091

Gilbody, S. M. (2018). The Current Status of Culturally Adapted Mental Health Interventions: A Practice-Focused Review of Meta-Analyses. Neuropsychiatric Disease \& Treatment, 14, 165-178. https://doi.org/10.2147/NDT.S138430

Sun, X. Q., Yu, R., \& Tian, H. Y. (2005). Analysis of Present Situation of Mental Health Teachers in Elementary Education and Study of Countermeasure. Journal of Chaohu College, 7, 148-149.

Wei, S. H. (2008). Study of Teachers' Professional Identity. Doctoral Dissertations, Chongqing: Xinan University.

Yu, H. H., \& Liu, Y. W. (2006). Study of Present Situation of Middle School Young Teachers' Professional Identity. Changsha: Hunan Normal University.

Zhang, S. S. (2011). Comparative Study of Special Grade Teachers and Ordinary Teachers' Professional Identity. Theory and Practice of Education (Primary and Secondary School Education), 31, 34-36. 